\title{
ANALYSIS OF FACTORS AFFECTING THE INDONESIAN SYARIAH STOCK INDEX (ISSI) ON THE INDONESIAN STOCK EXCHANGE (IDX)
}

\author{
Siska Angriani Hasibuan ${ }^{1 *}$, Armin Rahmansyah ${ }^{2}$ \\ ${ }^{1 *}$ Post Graduate Program, Universitas Negeri Medan \\ ${ }^{2}$ Faculty of Economics, Universitas Negeri Medan \\ Email: siskaangriani.hasibuan@yahoo.com
}

\begin{abstract}
The Indonesian Syariah Stock Index (ISSI) is an indicator that can be used by investors to know the movements of the sharia stock market. This research aims to analyze the effect of the Indonesian Syariah Stock Index (ISSI) on the Indonesian Stock Exchange (IDX). The analysis uses equations by the method of Error Correction Model (ECM). This study analyzed the relationship between the dependent and independent variables in both the short term and long term. Estimation results show that in the long term and the short term, the variable amount of the inflation was a positif and significant in the short term but not significant in the long term affect the Indonesian Syariah Stock Index (ISSI). The variable amount of the $B I$ rate and exchange rate was a negative and significant in the short term but not significant in the long term affect the Indonesian Syariah Stock Index (ISSI). These results show that inflation, BI rate and exchange rate was significant in the short term affect the Indonesian Syariah Stock Index (ISSI) on the Indonesian Stock Exchange (IDX).
\end{abstract}

Key words: Indonesian Syariah Stock Index (ISSI), Inflation, BI Rate, Exchange Rate, Error Correction Model (ECM)

\section{INTRODUCTION}

he capital market has a very important role in the economic development of a country, because with increasing capital gathered in an economy will be able to raise national income and employment for the economy will be able to raise national income and employment for the economy. Thus, the capital market is one of the means that are effective in moving the Community Fund for the next transmitted on productive activities. In Indonesia, the capital markets use the term stock exchanges. Where, the capital market is a meeting between parties that have excess funds with parties which needs the funds by way of trade in securities. Capital markets could also be interpreted as a market to trade in securities that generally have aged more than one year as stocks and bonds. While the place where happened and selling securities called Exchange. Therefore, the stock exchange is the meaning of physical capital markets.

Sharia capital market in Indonesia is getting lively with the birth of Indonesian Syariah Stock Index (ISSI) issued by the Bapepam-LK and the Board of the National Assembly of the Islamic Ulama Indonesia (DSN-MUI) on May 12, 2011. ISSI is an Islamic stock index 
that comprises all shares listed in the Indonesia stock exchange and is joined on the list of effects.

According to Syahrir (1995:81) to be able to answer whether the stock market will continue to grow on an ongoing basis then the most important factors determining depends on two things, namely the condition of macro economy Indonesia and political stability nationwide. So the development of Islamic stock index was also influenced by several macro-economic and monetary factors such as Bank Indonesia Certificate interest rate, inflation, exchange rates and other internal factors such as the condition of the national economy, the conditions politics, security, Government policy, and others.

The development of Indonesian Syariah Stock Index (ISSI) in Indonesia stock exchange (idx) for kurum time 2015 - 2017 fluctuating progression. In the year 2015, Indonesian Syariah Stock Index (ISSI) experienced a growing increase in i.e. from January 2015 until March 2015. With katipitalisasinya Rp 2,997,601.71 (Billion) to reach Rp 3,068,467.89 (billion) or experienced an increase of $1.69 \%$. But the following month decreased by $7.47 \%$. The decline of Indonesian Syariah Stock Index (ISSI) going to the Moon and back in Spetember increased until the end of December 2015. Of the curve below can be known that ISSI from January 2015 until December 2017 experiencing fluctuations in each period features. On average in the period of observation, i.e. Rp. ISSI value $3,069,621.312$. The value of the highest ISSI occurred in December 2017 i.e. Rp 3,704,543.09, while the lowest values of ISSI occurs in September 2015 i.e. Rp $2,449,104.28$. High low ISSI can reflect the development of Sharia capital market in Indonesia.

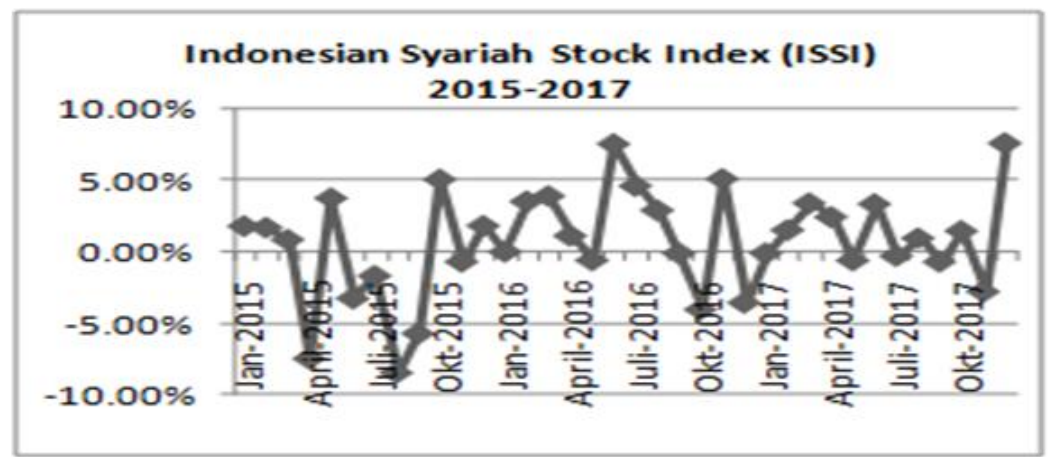

Figure 1: The development of Indonesian Syariah Stock Index 2015-2017

Based on the classical view that the main factors affecting inflation is the money supply and credit. View of keynes then add some variables such as interest rates, government spending and investment (Ackley,1983:543).

Table 1: The Development of Indonesian Syariah Stock Index (ISSI), Inflation BI Rate, Exchange Rate (Kurs) in Indonesia

\begin{tabular}{|l|l|l|l|l|}
\hline \multicolumn{1}{|c|}{ Month of Year } & \multicolumn{1}{c|}{ Capital ISSI (Milyar) } & \multicolumn{1}{c|}{ Inf } & \multicolumn{1}{c|}{ BI Rate } & \multicolumn{1}{c|}{ Kurs } \\
\hline January 2015 & 2997601 & 6.96 & 7.75 & 12672 \\
\hline February 2015 & 3045813 & 6.29 & 7.5 & 12932 \\
\hline March 2015 & 3068468 & 6.38 & 7.5 & 13074 \\
\hline
\end{tabular}




\begin{tabular}{|c|c|c|c|c|}
\hline April 2015 & 2852498 & 6.79 & 7.5 & 12963 \\
\hline May 2015 & 2960219 & 7.15 & 7.5 & 13224 \\
\hline June 2015 & 2863814 & 7.26 & 7.5 & 13339 \\
\hline July 2015 & 2813505 & 7.26 & 7.5 & 13539 \\
\hline August2015 & 2591624 & 7.18 & 7.5 & 14067 \\
\hline September 2015 & 2449104 & 6.83 & 7.5 & 14653 \\
\hline October 2015 & 2576748 & 6.25 & 7.5 & 13684 \\
\hline November 2015 & 2556257 & 4.89 & 7.5 & 13847 \\
\hline December 2015 & 2600851 & 3.35 & 7.5 & 13788 \\
\hline January 2016 & 2598203 & 4.14 & 7.25 & 13788 \\
\hline February 2016 & 2689933 & 4.42 & 7 & 13375 \\
\hline March 2016 & 2796013 & 4.45 & 6.75 & 13329 \\
\hline April 2016 & 2824409 & 3.6 & 6.75 & 13180 \\
\hline May 2016 & 2804579 & 3.33 & 6.75 & 13648 \\
\hline June 2016 & 3029644 & 3.45 & 6.5 & 13210 \\
\hline July 2016 & 3172188 & 3.21 & 6.5 & 13112 \\
\hline August 2016 & 3263157 & 2.79 & 5.25 & 13270 \\
\hline September 2016 & 3256322 & 3.07 & 5 & 13042 \\
\hline October 2016 & 3127302 & 3.31 & 4.75 & 13048 \\
\hline November 2016 & 3291469 & 3.58 & 4.75 & 13555 \\
\hline December 2016 & 3175053 & 3.02 & 4.75 & 13473 \\
\hline January 2017 & 3168780 & 3.49 & 4.75 & 13369 \\
\hline February 2017 & 3214256 & 3.83 & 4.75 & 13336 \\
\hline March 2017 & 3323611 & 3.61 & 4.75 & 13322 \\
\hline April 2017 & 3402986 & 4.17 & 4.75 & 13329 \\
\hline May 2017 & 3378520 & 4.33 & 4.75 & 13323 \\
\hline June 2017 & 3491395 & 4.37 & 4.75 & 13348 \\
\hline July 2017 & 3477373 & 3.88 & 4.75 & 13325 \\
\hline August 2017 & 3506954 & 3.82 & 4.5 & 13342 \\
\hline September 2017 & 3478918 & 3.72 & 4.25 & 13472 \\
\hline October 2017 & 3526648 & 3.58 & 4.25 & 13563 \\
\hline November 2017 & 3427607 & 3.3 & 4.08 & 13526 \\
\hline December 2017 & 3704543 & 3.61 & 3.96 & 13555 \\
\hline
\end{tabular}

Source: Central Bureau of Statistics (BPS), Bank Indonesia

Inflation in January 2015 experience increased until July 2015 up to $0.93 \%$. Then the following month until November 2015 decline. The development of the fluctuating inflation happen until 2017. According to Mankiw (2005:157) the interest rate is the price of connecting the present and future and constitutes an important variable between macroeconomic variables. Or the market price of transferring resources past and future or is the result of savings and the cost of borrowing (Mankiw, 2005:494). 
The development of the $\mathrm{BI}$ interest rate ( $\mathrm{BI}$ Rate) by the year 2015 on the 7.5 range experience. $\mathrm{BI}$ interest rate ( $\mathrm{BI}$ Rate) experienced a significant decline until 2017 December.

The movement of the exchange rate of the rupiah (exchange rate) from January to December 2015 - 2017 experienced trends that tend to rise with the volatility is very high, this is a reflection of the condition of the economy of the country. Over time, from January 2016 rupiah exchange rate of Rp 13.788/dollar. But entered February until the middle of March, the exchange rate of the rupiah gradually experience the appreciation. However, until December, school effects Trump, the rupiah exchange rate experience depreiasi 1.8 percent. The rupiah has been pushed back to positive sentiment and strengthened through December 2016 rupiah exchange rate of $\mathrm{Rp} \mathrm{13.743/dollar.} \mathrm{The}$ exchange rate of the rupiah tends to be stable through the year 2017.

In fact the company's share price is determined by the company's prospects in the future. The share price is a reflection of good corporate management by management to create and utilize business prospects, so take advantage and was able to fulfill his responsibilities towards the owners, employees, community, and Government. Therefore, the ability to analyze the operating and financial performance of the company as well as its market development will greatly help the success of the investment in the capital market. Based on the berlakang setting and observing the State of the economy continues to grow, the authors are interested in conducting a study entitled "analysis of the factors that Affect Indonesian Syariah Stock Index (ISSI) in Indonesia stock exchange (BEI) ".

The stock is the securities described the inclusion of capital into a company. While in principle the Sharia, the inclusion of capital carried out on companies - companies that do not violate the principle - the principle of Shariah, such as the field of gambling, usury, prohibited items such as producing beer and others (Sutedi, 2011). According to Kurniawan (2008), the stock of Sharia is shares issued by a company that has the characteristics in accordance with the Islamic Sharia.

Indonesian Syariah Stock Index (ISSI) is an indicator that can be used by investors to know the movement of the stock market. By looking at the figures of the index, then it can be known whether the current market movements increase or decrease from the previous one. The index serves as an indicator of market trends, that means the movement of an index describing market conditions at any given time.

According to Tandelilin (2010), inflation is the trend of increased prices of products as a whole so that's happening a decrease in the purchasing power of money. Whereas Sukirno (2006) explains that inflation is a process of rising prices are different in anything the economy. Further Perspective (2000) and Diantoro (2010) tells us that inflation is the increase in the prices of goods and services in a specific period of time. Inflation happens when prices continue creeping up as a result of economic growth or too the amount of money circulating in the market. When a country is experiencing high inflation and increase bersifatuncertainty (uncertain) then the risk of investing in the 
asset-inflated asetkeuangan and keredibilitas akanmelemah domestic currency against global currencies.

The interest rate is the amount of interest payable per unit of time is referred to as a percentage of the amount loaned (Samuelson and Nordhaus, 2004). The investment is also a function of the buga. The higher the interest rate, the desire of the community to make an investment also is getting smaller. The reason, an entrepreneur will increase spending on its investments in profits expected from the investment is greater than the interest rate to be paid to the investment fund is the cost for the use of funds (Cost of Capital). Lower interest rates, then employers would be more inclined to make investments, because the cost of the use of funds is also the more minor. According to Widoatmodjo (2007), the interest rate of Bank Indonesia (BI-rate) is the interest rate in response to changes in inflation and exchange rate of the rupiah as a reference to the banking interest rates.

Mankiw (2006) translation Chriswan Sungkono, the exchange rate is the value used when someone exchanged the currency of a country with the currency of other countries. So the exchange rate is the USD/INR value or the price of the rupiah which is expressed in dollars, where the value is affected by supply and demand. Exchange rates will affect the sectors trade import export-related. Fluctuations in the value of the uncontrolled rate can affect the performance of companies listed on the stock market. At a time when the value of the rupiah terdespresiasi United States dollars, with the price of imported goods become more expensive, especially for a company that most raw material use of imported products. The increase in the import of such materials will automatically increase the cost of production and in the end they would affect the rate of decline in corporate profits, so this will have an impact on the company's share price movement then trigger against weakening of the movement of the stock price index.

\section{RESEARCH METHOD}

Approach this research using a quantitative approach, namely by means of measuring the variables that are encircled by theory or a set theory (conceptual framework). data collection is done using secondary data sourced from the Central Bureau of statistics (BPS), the financial services authority (OJK), Bank Indonesia (BI) and of the related reading material. The data used in this research in the form of time series data (runtun time) with a span of 3 years i.e. from January 2015 until December 2017.

The estimation model used in this study is the analysis of Error Correction Model (ECM) or known by the error correction model is a model that is used to look at the influence of long term and short term from each of the independent variables are bound against free (Satria, 2004). According to Sargan, Engle and Granger, error correction model is a technique for correcting an imbalance towards short term long term balance, and may explain the relationship between the variables bound to the free variables on time now and time past. This analysis is performed to correct imbalances in the short term towards the long term. This study uses statistics programs help E-Views of version 7. 


\section{RESULT AND DISCUSSION}

\section{Stationeritas Test}

The first thing to do is to examine whether the data is stationary or not. This Stasioneritas test needs to be done because a regression analysis should not be did when the data used is not stationary and normally if it still done the resulting equations then are a spurious regression.

\section{Unit Root Test}

The unit root test is the normal testing that was introduced by David Dickey and Wayne Fuller. The root test is done to find out whether the data used stationary or not. Data of stationary time series data that does not contain a root unit and vice versa.

Table 2: Unit Root Test Results

\begin{tabular}{|l|l|l|l|}
\hline \multicolumn{1}{|c|}{ Variables } & \multicolumn{1}{|c|}{ Value ADF } & \multicolumn{1}{c|}{$\begin{array}{c}\text { Critical Value } \\
\text { McKinnon }(\boldsymbol{\alpha}=\mathbf{5 \%})\end{array}$} & \multicolumn{1}{c|}{ Ket } \\
\hline ISSI & -4.969355 & -2.948404 & Stasionary \\
\hline INF & -1.586033 & -2.948404 & Non Stasionary \\
\hline BI Rate & 0.165503 & -2.948404 & Non Stasionary \\
\hline Kurs & -3.143863 & -2.948404 & Stasionary \\
\hline
\end{tabular}

Based on the chart above, showing that all variables have not been stationary at level I or level (O). This is because the value of the probability for a variable inflation rates and BI Rate probability value greater than $\alpha=5 \%$ and the value of the ADF t-statistics are smaller than the critical value (Mackinon Critical Values) at $\alpha=5 \%$. Thus, testing continued with the test of the degree of integration.

\section{Integration Test}

A test of the degree of integration is a test done to measure at the level of diferensi to how data all the variables are stationary. The method used is the method Agumented Dickey Fuller (ADF) that is by comparing a value to calculate the absolute value of the ADF the ADF critical $\alpha=5 \%$. If the data is still not stationary then this is done by the method of testing with the next level of differentiation to stationary data on the same level.

Table 3: Integration Test Results

\begin{tabular}{|l|l|l|l|}
\hline \multicolumn{1}{|c|}{ Variables } & \multicolumn{1}{|c|}{ Value ADF } & \multicolumn{1}{c|}{$\begin{array}{c}\text { Critical Value } \\
\text { McKinnon ( } \mathbf{\alpha = 5 \% )}\end{array}$} & \multicolumn{1}{c|}{ Ket } \\
\hline ISSI & -9.773489 & -2.948404 & Stasionary \\
\hline INF & -5.146643 & -2.951125 & Stasionary \\
\hline BI Rate & -4.921036 & -2.951125 & Stasionary \\
\hline Kurs & -6.995325 & -2.951125 & Stasionary \\
\hline
\end{tabular}


Based on the above table of results test of the degree of integration (first diferrence) above, to see that all the variables i.e. Indonesian Syariah Stock Index (ISSI), BI Rate, inflation, and exchange rates (exchange rate) has been stationary since smaller probability value at $\alpha=5 \%$ and larger ADF t-statistics compared to the critical value (Mackinon Critical Values) at $\alpha=5 \%$.

\section{Cointegration Test}

In this research for the residual method using Granger test based test. Residual based test method using statistical tests Agumented Dickey Fuller (ADF) i.e. by observing the regression residual Granger stationary or not. Then this residual value will be tested using the test Agumented Dickey Fuller (ADF) to find out if the residual value of the stationary or not. The results of this research show that the estimated value of the ADF test > Critical Value $\alpha=5 \%(-6.412763>-2.948404)$. So it could be inferred that the empirical model used in this study to qualify for the cointegration test.

Table 4: Cointegration Test Results

\begin{tabular}{|l|l|l|l|}
\hline \multicolumn{1}{|c|}{ Variables } & \multicolumn{1}{|c|}{ Value ADF } & $\begin{array}{c}\text { Critical Value } \\
\text { McKinnon }(\boldsymbol{\alpha}=\mathbf{5 \%})\end{array}$ & \multicolumn{1}{c|}{ Ket } \\
\hline ECT & -6.412763 & 0.0000 & Stasionary \\
\hline
\end{tabular}

\section{Estimation Error Correction Model (ECM)}

Estimation model of ISSI using the model of Error Correction Model (ECM). To know that a used Error Correction Model (ECM) is valid or not can be seen from the value of the Error Correction Term (ECT) are significant or not. Equation Error Correction Model (ECM) for short-term period are as follows:

$$
\begin{gathered}
D\left(\text { InISSIt }_{t}\right)=232,8617--0,693554 \text { INF }--0,329883 \text { BI_Rate }--0,871180 \text { KURS }_{t}+ \\
0,526368 \mathrm{ECT}+\varepsilon i
\end{gathered}
$$

Table 5: The Results of The Estimation of the Error Correction Model (ECM) Short-Term

\begin{tabular}{|l|l|l|l|}
\hline Independent Variables & Coefficient & t-Statistic & Prob \\
\hline $\mathrm{D}($ LNINF) & -0.693554 & -0.208781 & 0.8362 \\
\hline $\mathrm{D}($ LNSBI) & -0.329883 & -0.305303 & 0.7625 \\
\hline $\mathrm{D}($ LNKURS) & -0.871180 & -0.043955 & 0.9653 \\
\hline $\mathrm{ECT}$ & 0.526368 & 21.28540 & 0.0000 \\
\hline $\mathrm{C}$ & 232.8617 & 5.890509 & 0.0000 \\
\hline \multicolumn{2}{|l|}{ R-squared } & & \\
Adjusted R-squared & 0.954614 & \\
F-statistic & 0.942847 & \\
Prob(F-statistic) & 81.12831 & \\
Durbin-Watson stat & 0.000000 & \\
\hline
\end{tabular}

The results of the estimation of ECM above shows that short-term changes in interest rates, Inflation variable $\mathrm{BI}$ (BI Rate), and exchange rates (exchange rate) have a negative effect against Indonesian Syariah Stock Index (ISSI), cateris paribus. The magnitude of the balance and changes in Islamic Indonesia stock index (ISSI) against previous period 
now was $52.64 \%$. These adjustments are obtained from coefficients ECT of 0,526368. While t-his statistics are 21.28540 with probabilities $(0.0000<0.05)$, so significant at $\alpha$ $=5 \%$ and means that the model can be used.

Equation Error Correction Model (ECM) for long-term periods are as follows:

$$
\text { InISSI } \mathrm{t}_{-1}=232.8617+2.039721 \mathrm{INF}--3.239223 \mathrm{BI} \_ \text {Rate }--98.53454 \mathrm{KURS}_{\mathrm{t}}+\varepsilon \mathrm{i}
$$

Table 6: The Results of The Estimation of Error Correction Model (ECM) Long-Term

\begin{tabular}{|l|l|l|l|}
\hline \multicolumn{1}{|c|}{ Independent Variables } & \multicolumn{1}{c|}{ Coefficient } & \multicolumn{1}{c|}{ t-Statistic } & Prob \\
\hline LNINF(-1) & 2.039721 & 2.734483 & 0.0109 \\
\hline LNSBI(-1) & -3.239223 & -5.354096 & 0.0000 \\
\hline LNKURS(-1) & -98.53454 & -5.854761 & 0.0000 \\
\hline C & 232.8617 & 5.890509 & 0.0000 \\
\hline \multicolumn{1}{|c|}{ R-squared } & 0.954614 & \\
Adjusted R-squared & 0.942847 & \\
F-statistic & 81.12831 & \\
Prob(F-statistic) & 0.000000 & \\
Durbin-Watson stat & 2.777986 & \\
\hline
\end{tabular}

The results of the estimation of ECM above show that long-term changes in the variable interest rates on $\mathrm{BI}$ (BI Rate) and exchange rates (exchange rate) of previous periods have a negative influence on the stock index of Sharia against Indonesia (ISSI), cateris paribus. So it is with the previous period Inflation variables that have a positive influence against Indonesian Syariah Stock Index (ISSI).

\section{F-Test (Simultaneous Test)}

Based on the results of the processing of data by the method of Error Correction short and long term Model obtained the value of R Squared of 0.954614 with which means the variable inflation rate, the $\mathrm{BI}$ Rate, and exchange rates (exchange rate) affect Indonesian Syariah Stock Index (ISSI) in IDX amounting to $95.46 \%$.

Based on the results of the processing of data by the method of Error Correction Model of short and long term value of the obtained $F$ count of 81.12831 with the probability of 0.00000 greater than $\alpha=5 \%$ therefore $\mathrm{HO}$ is accepted. Then the variable inflation rate, the $\mathrm{BI}$ Rate, and exchange rates (exchange rate) in the short run and the long run insignificant together against Indonesian Syariah Stock Index (ISSI) in IDX.

\section{Inflation}

Based on the results of the study showed that changes the level of inflation in the short term negative effect to changes in Indonesian Syariah Stock Index (ISSI) in BEI with a coefficient of- 0.693554 . In the short term that the statistics of 0.208781 smaller than the t-table $(-0.208781>2.03693)$ and a smaller probability $(0.8362>0.05)$ then the Ho is rejected. This means that in the short term inflation rate have an effect that is not significant and marked negative against Indonesian Syariah Stock Index (ISSI) in IDX.

While in the long-term government change inflation rate long term positive effect to changes in Indonesian Syariah Stock Index (ISSI) in the BEI by a coefficient of 2.039721 . In the long term that the t-statistic of 2.734483 greater than t-table $(2.734483<$ 
$2.03693)$ and a smaller probability $(0,0109>0.05)$ then Ho accepted. This means that in the long run inflation rate significantly to the influential Indonesian Syariah Stock Index (ISSI) in IDX.

\section{BI Rate}

Based on the results of the study showed changes in the BI Rate in the short term to change Indonesian Syariah Stock Index (ISSI) in BEI with a coefficient of-0.329883. In the short term that the t-statistics registration- 0.305303 smaller than the t-table $(-0.305303$ $<2.03693)$ and greater probability $(0.7625>0.05)$ then the Ho is rejected. This means that in the short term the BI Rate influence is not significant and marked negative against Indonesian Syariah Stock Index (ISSI) in IDX.

While in the long-term BI Rate negative effect to changes in Indonesian Syariah Stock Index (ISSI) in BEI with a coefficient of-3.239223. In the long run bahwat-statistics registration 5.354096 more besardari t-table $(5.354096>2.03693)$ and greater probability $(0.0000>0.05)$ then Ho accepted. Then the variable BI Rate in the long run have significant influence towards Islamic Indonesia stock index (ISSI) in IDX.

\section{The Exchange Rate}

Based on the results of the study showed that changes in exchange rates (exchange rate) in the short term have no effect against Islamic Indonesia stock index changes (ISSI) in BEI with a coefficient of-0.871180. In the short term that the t-statistic of 21.28540 greater than t-table $(21.28540>2.03693)$ and greater probability $(0.9653>0.05)$ then the $\mathrm{Ho}$ is rejected. This means that in the short term exchange rates (exchange rate) does not have significant influence towards Indonesian Syariah Stock Index (ISSI) in IDX.

While in the long term changes in exchange rates (exchange rate) against the potential negative effect long-term change in Indonesian Syariah Stock Index (ISSI) in BEI with a coefficient of-98.53454. In the long term that the t-statistic of 5.890509 greater than $\mathrm{t}$ table $(5.890509>2.03693)$ and greater probability $(0.0000>0.05)$ then Ho accepted. Then the variable exchange rates (exchange rate) over the long term have significant influence towards Indonesian Syariah Stock Index (ISSI) in IDX.

\section{CONCLUSIONS AND RECOMMENDATIONS}

\section{Conclusion}

Based on the results of research and discussion, then the conclusions of this research is the existence of a negative influence in the short term between variable inflation rate, the BI Rate and exchange rates against Indonesian Syariah Stock Index (ISSI) and yet not significant. While for the long term, the inflation rate has a positive influence against Islamic Indonesia stock index (ISSI) and significant. But, the BI Rate and the exchange rate has a negative influence against Indonesian Syariah Stock Index (ISSI) and significant on the Indonesia stock exchange (BEI) in Indonesia.

\section{REFERENCES}


Arif, M. Nur Rianto. 2010. Teori Makroekonomi Islam. Bandung: Alfabeta.

Ardana, Yudhistira. "Pengaruh Variabel Makroekonomi Terhadap Indeks Saham Syariah Di Indonesia". Hal. 28.

Asnaini, dkk. 2012. Manajemen Keuangan. Yogyakarta: Teras.

Aziz, Abdul. 2010. Manajemen Investasi Syariah. Bandung: Alfabeta.

Darmadji, T dan H. M. Fakhruddin. 2011. Pasar Modal Di Indonesia. Edisi Ketiga. Salemba Empat. Jakarta.

Fahmi, Irham. 2006. Analisis Investasi dalam Perspektif Ekonomi dan Politik. Bandung. PT. Refika Aditama.

Fatimah, Ade Lubis. 2008. Pasar Modal,Jakarta. Lembaga Penerbit FE UI.

Firdaus, Muhammad, dkk. 2005. Sistem Keuangan Syariah dan Investasi Syariah. Jakarta: Renaisan.

Firdaus, Mikail. "Analisis Pengaruh Variabel Makroekonomi Terhadap Indeks Saham Syariah Indonesia". Hal. 131.

Gujarati, Damodar. 1991. Ekonometrika Dasar, Terjemahan oleh Sumarno Zain. Jakarta :Erlangga

Huda, Nurul \& Mohamad Heykal. 2010. Investasi pada Pasar Modal Syariah. Jakarta: Kencana.

Karim, Adiwarman A. 2004. Fikih Ekonomi Keuangan Islam. Jakarta: Darul Hak.

Kasmir. 2003. Bank dan Lembaga Keuangan. Jakarta: PT. Raja Grafindo Persada.

Mankiw, N. Gregory. 2006. Macroeconomics. United State: Worth Publisher, t.t. Diterjemahkan oleh Fitria Liza dan Imam Nurmawan, Makroekonmi. Jakarta: Erlangga.

Mishkin, Frederic. 2008. Ekonomi Uang, Perbankan dan Pasar Keuangan, Edisi8. Jakarta: Salemba Empat

Manurung, Jonni \& Adler Haymans Manurung, Ekonomi Keuangan dan Kebijakan Moneter. Jakarta: Erlangga.

Nasir, Muhammad, Fakriah, Ayuwandirah. "Analisis Variabel Makroekonomi Terhadap Indeks Saham Syariah Indonesia". Hal. 62.

Nopirin.1992. Ekonomi Moneter. BPFE : Yogyakarta.

Paramita, Alina. "Analisis Pengaruh Indikator Makroekonomi, Indeks Harga Saham Gabungan, Bursa Saham Syariah Internasional Terhadap Indeks Saham Syariah Indonesia". Hal, 100-101.

Purnawan, Irfan. "Analisis Pengaruh Makroekonomi Domestik Dan Makroekonomi Global Terhadap Indeks Saham Syariah Indonesia (ISSI) Periode 2011-2014". Hal. 
27.Suciningtias, Siti Aisiyah dan Rizki Khoiroh "Analisis Dampak Variabel Makro Ekonomi Terhadap Indeks Saham Syariah Indonesia (ISSI)". Hal. 410.

Samuelson,P.A, Nordhaus,W.D, 2004. Ilmu Makroekonomi, Edisi Tujuh Belas, Jakarta: PT. Media Golbal Edukasi.

Tandeliin, Eduardus. 2001. Analisis Investasi dan Manajemen Portofolio. Yogyakarta: BPFE.

Wahyuningrum, Meylani. "Analisis Faktor-Faktor Yang Mempengaruhi Indeks Saham Syariah Indonesia (ISSI)". Hal. 12-13.

www.bi.go.id

www.bps.go.id

www.idx.co.id 